\title{
PENGARUH KINERJA KEUANGAN TERHADAP PERINGKAT OBLIGASI DENGAN MANAJEMEN LABA SEBAGAI VARIABEL INTERVENING PADA PERUSAHAAN MANUFAKTUR YANG TERDAFTAR DI BEI
}

\author{
Siti Chaerunisa Prastiani \\ Universitas Esa Unggul \\ pribadisitichaerunisa@gmail.com
}

\begin{abstract}
This research is about financial performance represented by Return On Common Equity, Current Ratio, Dept To Equity Ratio, Total Assets Turn Over, to Bond Rating and Profit Management as intervening variable which is meticulously by 6 manufacturing companies within 11 years from year 2005 - 2015. This research uses Path Analized (Path Analysis) processed by SPSS 23 and get results, financial performance simultaneously affect the earnings management, ROCE has no effect on earnings management, CR, DER and TATO influence earnings management, financial performance and earnings management simultaneously affect bond rating, ROCE and TATO affect bond rating, CR and DER have no effect on bond rating. This study also shows the direct and indirect variables, Earnings Management does not mediate ROCE and CR variables, Profit Management mediates DER and TATO variables, and Earnings variable intervening between ROCE, CR, DER and TATO simultaneously against Bond Rating.
\end{abstract}

Keywords : Financial Performance (Return On Common Equity, Current Ratio, Dept To Equity Ratio, Total Assets Turn Over), Bond Rating, Earnings Management

\begin{abstract}
Abstrak
Penelitian ini mengenai kinerja keuangan yang di wakili oleh Return On Common Equity, Current Ratio, Dept To Equity Ratio, Total Assets Turn Over, terhadap Rating Obligasi dan Manajemen Laba sebagai variabel intervening yang di teliti oleh 6 perusahaan manufaktur dalam jangka waktu 11 tahun dari tahun 2005 2015. Penelitian ini menggunakan Path Analized (Analisis Jalur) yang diolah oleh SPSS 23 dan mendapatkan hasil, kinerja keuangan secara simultan berpengaruh terhadap manajemen laba, ROCE tidak berpengaruh terhadap manajemen laba, CR, DER dan TATO berpengaruh terhadap manajemen laba, kinerja keuangan dan manajemen laba secara simultan berpengaruh terhadap rating obligasi, ROCE dan TATO berpengaruh terhadap Rating obligasi, CR dan DER tidak berpengaruh terhadap rating obligasi. Penelitian ini juga memperlihatkan variabel langsung dan
\end{abstract}


tidak langsung, Manajemen Laba tidak memediasi variabel ROCE dan CR, Manajemen Laba memediasi variabel DER dan TATO, dan Manajemen Laba variabel intervening antara ROCE, CR, DER dan TATO secara simultan terhadap Rating Obligasi.

Keywords : Kinerja Keuangan (Return On Common Equity, Current Ratio, Dept To Equity Ratio, Total Assets Turn Over), Peringkat Obligasi, Manajemen Laba.

\section{LATAR BELAKANG}

Perusahaan manufaktur merupakan penopang utama perkembangan industri di sebuah Negara. Perkembangan ini dapat dilihat baik dari aspek kualitas produk yang dihasilkan maupun kinerja industri secara keseluruhan.begitu pula di Indonesia, sektor manufaktur berpeluang untuk terus berkembang, meningkatnya laju pertumbuhan industri permintaan domestik, terutama untuk logam, makanan, bahan kimia, dan suku cadang otomotif.

Pasar modal tempat berbagai perusahaan menjual saham (stock) dan obligasi (bond) dengan tujuan hasil penjualan tersebut nantinya akan dipergunakan sebagai tambahan dana atau untuk memperkuat modal perusahaan. Investasi obligasi merupakan jenis investasi yang banyak diminati oleh pemilik modal (investor) karena obligasi memiliki pendapatan yang bersifat tetap. Pendapatan tetap tersebut diperoleh dari pokok obligasi dan bunga yang akan diterima secara periodik pada saat jatuh tempo. Keuntungan yang diperoleh dari investasi obligasi adalah pemegang obligasi memiliki hak pertama atas aset perusahaan jika perusahaan yang bersangkutan mengalami likuidasi karena perusahaan telah mengikat kontrak untuk dapat melunasi obligasi yang telah dibeli oleh pemegang obligasi. Investasi obligasi relatif lebih baik dan aman dibandingkan dengan investasi saham. Obligasi lebih disukai perusahaan yang membutuhkan tambahan dana karena lebih mudah didapatkan. Namun, obligasi merupakan suatu jenis investasi yang memiliki beberapa risiko bagi investor. Salah satu risiko yang dapat muncul adalah ketidakmampuan perusahaan untuk melunasi obligasi kepada investor atau dapat disebut dengan obligasi macet, Annas (2015).

Sebelum ditawarkan, obligasi harus diperingkatkan oleh suatu lembaga atau agen pemeringkat obligasi (Rating Agency). Agen pemeringkat obligasi adalah lembaga independen yang memberikan informasi pemeringkatan skala risiko ,di mana salah satunya adalah sekuritas obligasi sebagai petunjuk sejauh mana keamanan suatu obligasi bagi investor. Keamanan tersebut ditunjukkan oleh kemampuan suatu perusahaan dalam membayar bunga dan melunasi pokok pinjaman. Sehingga pemodal bisa menggunakan jasa agen pemeringkat obligasi tersebut untuk mendapatkan informasi mengenai peringkat obligasi. Proses peringkatan ini dilakukan untuk menilai kinerja perusahaan, sehingga rating agency dapat menyatakan layak atau tidaknya obligasi tersebut diinvestasikan. 
Layak atau tidak obligasi tersebut dapat dilihat dari menganalisis rasio untuk membimbing investor dan kreditor untuk membuat keputusan atau pertimbangan tentang pencapaian perusahaan dan prospek pada masa datang. Salah satu cara pemrosesan dan penginterpretasian informasi akuntansi, yang dinyatakan dalam artian relatif maupun absolut untuk menjelaskan hubungan tertentu antara angka yang satu dengan angka yang lain dari suatu laporan keuangan. Semakin baik rasio-rasio keuangan tersebut semakin tinggi rating obligasi suatu perusahaan. Salah satu cara agar laporan keuangan terlihat baik adalah dengan melakukan manajemen laba.

Manajemen laba mengukur kinerja perusahaan tahunan dan dihitung sebagai hasil bersih dari pendapatan dan beban untuk tahun fiskal. Manajer karena berbagai alasan dapat mempengaruhi hasil dengan intervensi atau "memanipulasi" angka. Intervensi ini pada laba akuntansi oleh manajer dikenal dengan "manajemen laba". Menurut Healy dan Whalen (1999:368) dalam Liukani (2013), manajemen laba terjadi ketika manajer menggunakan penilaian dalam pelaporan keuangan dan transaksi penataan untuk mengubah laporan keuangan baik menyesatkan beberapa stakeholder tentang kinerja ekonomi yang mendasari perusahaan atau untuk mempengaruhi hasil kontrak yang tergantung pada angka akuntansi yang dilaporkan.

Manajemen laba dilakukan oleh pihak manajer dalam proses pelaporan keuangan suatu perusahaan karena pihak manajer ingin mengharapkan apa yang telah mereka lakukan. Penelitian mengenai manajemen laba menjadi pusat perhatian oleh kalangan praktisi, investor maupun pemegang saham yang memiliki kepentingan terhadap laporan keuangan perusahaan. Manajemen laba menarik untuk diteliti karena dapat memberikan gambaran tentang perilaku manajer dalam pelaporan kegiatan usahanya pada periode tertentu dan kemungkinan munculnya motivasi untuk memanage data keuangan yang dilaporkan. Pihak manajemen tidak berusaha memanipulasi data tetapi lebih cenderung dengan pemilihan metode akuntansi untuk mendapatkan keuntungan yang memang diperkenankan menurut accounting regulations (Pambudi dan Sumantri, 2014).

\section{KAJIAN TEORI}

\subsection{Tela'ah Teori Dan Pengembangan Hipotesis}

\subsubsection{Signaling Theory}

Teori signal menjelaskan alasan perusahaan menyajikan informasi untuk pasar modal. Menunjukan adanya asimetri informasi antara manajemen perusahaan dan pihak-pihak yang berkepentingan dengan informasi tersebut. (wolk, et al. 2001).

\subsubsection{Teori Akuntansi Positif}

PAT berpendapat bahwa kebijakan akuntansi perusahaan akan dipilih sebagai bagian dari masalah minimalisasi biaya pengadaan kontrak yang lebih luas, seperti untuk mencapai pengelolaan perusahaan yang efisien. memprediksi 
bahwa semakin besar integrasi/penyatuan antara perusahaan induk dengan perusahaan cabang maka semakin besar kemungkinan perusahaan induk akan mempersiapkan laporan keuangan (Mian dan Smith 1990).

\subsubsection{Peringkat Obligasi}

Peringkat obligasi disarakan atas faktor-faktor kualitatif dan kuantitatif rasio keuangan, ketentuan hipotik, ketentuan subordinasi, ketentuan, dana, jatuh tempo, stabilitas, regulasi, antitrust, faktor lingkungan, kewajiban atas produk, kewajiban pensiun, masalah ketenagakerjaan, dan kebijakan akuntansi. Peringkat obligasi menunjukan kualitas kredit perusahaan penerbit. Semakin dekat peringkat obligasi dengan AAA berarti semakin bagus peringkatnya dan semakin kecil kemungkinan obligasi akan gagal dalam memenuhi kewajiban membayar bunga dan pokok pinjamannya. ( Brigham 2010).

\subsubsection{Kinerja Keuangan, Profiabilitas}

Rasio yang digunakan untuk mengukur kemampuan perusahaan menghasilkan laba dan juga untuk mengetahui efektifitas perusahaan dalam mengelola sumber-sumber yang dimilikinya. Apabila laba perusahaan tinggi maka akan memberikan peringkat yang naik pula sehingga variabel ini dikatakan dapat mempengaruhi prediksi peringkat obligasi. Profitabilitas atau kemampuan memperoleh laba adalah suatu ukuran dalam presentase yang digunakan untuk menilai sejauh mana perusahaan mampu menghasilkan laba pada tingkat yang diterima

\subsubsection{Kinerja Keuangan, Likuiditas}

Likuiditas menunjukkan kemampuan perusahaan untuk membayar kewajiban finansial jangka pendek tepat pada waktunya. Likuiditas ditunjukkan oleh besar kecilnya aktiva lancar. Likuiditas perusahaan ditunjukkan oleh besar kecilnya aktiva lancar, yaitu aktiva yang mudah untuk diubah menjadi k as yang meliputi kas, surat berharga, piutang, persediaan (Sari 2011).

\subsubsection{Kinerja Keuangan, Leverage}

Rasio leverage digunakan untuk mengukur sejauh mana suatu perusahaan menggunakan utang dalam membiayai investasinya. Rendahnya nilai rasio leverage dapat diartikan bahwa hanya sebagian kecil aktiva didanai dengan utang dan semakin kecil risiko kegagalan perusahaan. Dengan demikian, semakin rendah leverage perusahaan maka akan semakin tinggi peringkat yang diberikan pada perusahaan. (Magreta 2009).

\subsubsection{Kinerja Keuangan, Aktivitas}

Rasio aktivitas adalah rasio yang mengukur seberapa efektif perusahaan dalam memanfaatkan semua sumber daya yang ada padanya. Semua rasio aktivitas ini melibatkan perbandingan antara tingkat penjualan dan investasi pada berbagai jenis aktiva. Rasio-rasio aktivitas menganggap bahwa sebaiknya terdapat keseimbangan yang layak antara penjualan dan beragam unsur aktiva misalnya persediaan, aktiva tetap dan aktiva lainnya. 


\subsubsection{Manajemen Laba}

Manajemen laba terjadi ketika para manajer menggunakan keputusan tertentu dalam melaporkan keuangan dan mengubah transaksi untuk mengubah laporan keuangan sehingga menyesatkan stakeholder yang ingin mengetahui kinerja ekonomi yang diperoleh perusahaan atau untuk mempengaruhi hasil kontrak yang menggunakan angka-angka akuntansi yang dilaporkan itu. (Healy dan Wahlen 1999)

\subsection{Hipotesis}

\subsubsection{Pengaruh Profitabilitas terhadap Peringkat Obligasi}

Profitabilitas bisa digunakan sebagai pelengkap analisis risiko, karena kemampuan perusahaan menghasilkan keuntungan mencerminkan kemampuan perusahaan memperoleh aliran kas masuk. Perusahaan yang profitabilitasnya tinggi akan memeperoleh aliran kas masuk yang baik, dengan demikian mencerminkan risiko yang lebih kecil sehingga peringkat obligasi lebih baik.

\subsubsection{Pengaruh Likuiditas terhadap Peringkat Obligasi}

Burton et al (2000) dalam Almilia dan Devi (2007) menyatakan bahwa tingkat likuiditas yang tinggi akan menunjukkan kuatnya kondisi keuangan perusahaan sehingga secara finansial akan mempengaruhi prediksi peringkat obligasi. Hal ini didukung Almilia dan Devi (2007) dalam penelitiannya yang menunjukkan bahwa variabel likuiditas yang diukur dengan current ratio, merupakan variabel yang dominan untuk memprediksi peringkat obligasi.

\subsubsection{Pengaruh Leverage terhadap Peringkat Obligasi}

Rasio ini digunakan untuk mengukur sejauh mana perusahaan menggunakan utang dalam membiayai investasinya. Jika rasio ini cukup tinggi, maka hal tersebut menujukkan tingginya penggunaan utang, sehingga hal ini dapat membuat perusahaan mengalami kesulitan keuangan, dan biasanya memiliki resiko kebangkrutan yang cukup besar. Dengan demikian dapat disimpulkan semakin rendah leverage maka akan semakin baik peringkat obligasi.

\subsubsection{Pengaruh Aktivitas terhadap Peringkat Obligasi}

Rasio ini digunakan untuk mengukur efisiensi pemanfaatan sumber daya perusahaan. Efisiensi yang dilakukan misalnya di bidang penjualan, persediaan, penagiahan piutang dan efisiensi di bidang lainya. Total Assets Turn Over merupakan rasio yang digunakan untuk mengukur perputaran semua aktiva yang dimiliki perusahaan dan mengukur berapa jumlah penjualan yang diperoleh dari tiap rupiah aktiva, dengan kata lain, bila rasio ini meningkat maka peringkat obligasi pun membaik.

\subsubsection{Pengaruh Manajemen Laba terhadap Peringkat Obligasi}

Peringkat obligasi suatu perusahaan dapat dipengaruhi oleh manajemen laba dengan cara yang sama dengan emisi obligasi yaitu menaikkan laba sebuah perusahaan sehingga kinerja perusahaan terlihat baik di mata investor, dan 
investor pada akhirnya mempercayakan memberikan utang kepada perusahaan. Manajemen sebuah perusahaan diduga cenderung melakukan manajemen laba atau rekayasa laba pada periode di sekitar emisi obligasi agar kinerja perusahaan terlihat baik karena akan berdampak pada perolehan peringkat obligasi sehingga akan meningkatkan daya tarik perusahaan di mata para kreditur.

H1 : Diduga ROCE, CR, DER, TATO berpengaruh simultan positif dan signifikan terhadap Manajemen Laba.

H2 : Diduga ROCE berpengaruh positif dan signifikan terhadap Manajemen Laba.

H3 : Diduga CR berpengaruh positif dan signifikan terhadap Manajemen Laba.

H4 : Diduga DER berpengaruh positif dan signifikan terhadap Manajemen Laba.

H5 : DidugaTATO berpengaruh positif dan signifikan terhadap Manajemen Laba.

H6 : Diduga ROCE, CR, DER, TATO berpengaruh simultan positif dan signifikan terhadap Rating Obligasi.

H7 : Diduga ROCE berpengaruh positif dan signifikan terhadap Peringkat Obligasi.

H8 : Diduga CR berpengaruh positif dan signifikan terhadap Peringkat Obligasi.

H9 : Diduga DER berpengaruh positif dan signifikan terhadap Peringkat Obligasi.

H10 : Diduga TATO berpengaruh positif dan signifikan terhadap Peringkat Obligasi.

H11 : Diduga Manajemen Laba berpengaruh positif dan signifikan terhadap Peringkat Obligasi.

\section{Model Penelitian}

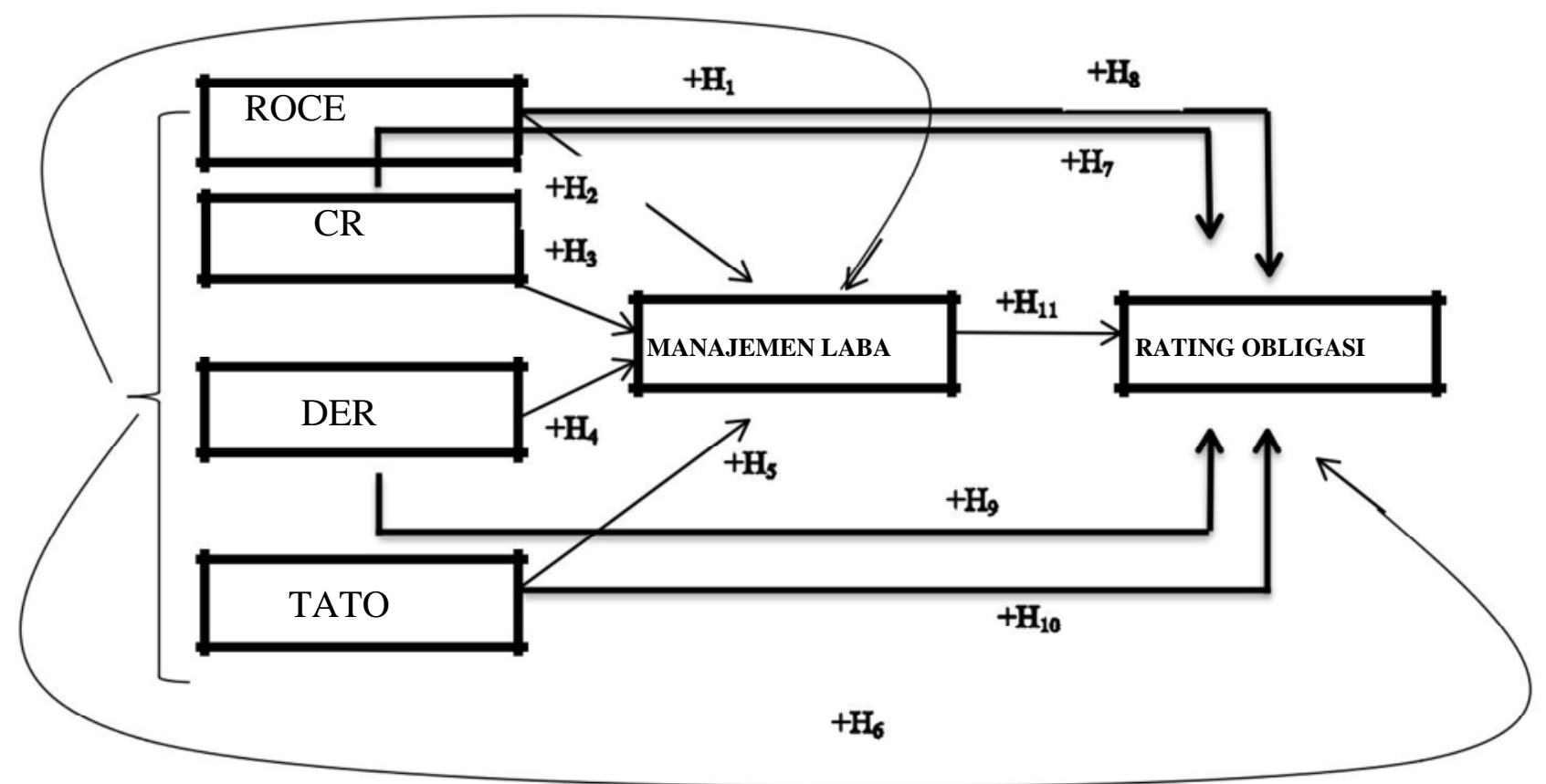




\section{METODOLOGI PENELITIAN}

\subsection{Jenis Penelitian}

Penelitian ini adalah penelitian kausalitas atau sebab akibat. Penelitian ini merupakan penelillltian kuantitatif sehingga penyaJIAn data dapat berupa angka.

\subsection{Jenis dan Sumber Data}

Data yang digunakan dalam penelitian ini adalah data sekunder, yaitu laporan keuangan yang menyajikan unsur rasio keuangan, manajemen laba, dan rating oblgasi.. Data tersebut tersedia di website di BEI yang tersedia secara online pada situs http:/www.idx.co.id selain itu juga peringkat obligasi yang dapat diakses di website PT.PEFINDO pada situs http://new.pefindo.com

\subsection{Populasi dan Sampel}

Penelitian ini menggunakan populasi semua perusahaan go public yang menerbitkan obligasi dan perusahaan manufaktur tersebut terdaftar di Bursa Efek Indonesia (BEI) serta terdaftar dalam peringkat obligasi yang dikeluarkan PT. PEFINDO. Periode laporan keuangan adalah data periode tahun 2012-2015 sebanyak 144 perusahaan Manufaktur.

\subsection{Variabel Penelitian}

\subsubsection{Rasio Keungan}

\subsubsection{Rasio Profitabilitas}

Rasio Profitabilitas adalah mengukur kemampuan perusahaan mendapatkan laba dari modal yang dimiliki. Rasio profitabilitas di hitung dengan mengunakan alat ukur (Return on common equity) ROCE = EBIT : (Rata-rata Total Aset - Total Hutang - Saham Preferen).

\subsubsection{Rasio Likuiditas}

Rasio likuiditas adalah kemampuan perusahaan dalam melunasi kewajiban jangka pendek perusahaan. Rasio likuiditas dihitung dengan Current Ratio $(\mathrm{CR})=$ Aktiva lancar : Utang lancar.

\subsubsection{Rasio Leverage}

Rasio leverage menunjukan proporsi penggunaan modal untuk mnjamin hutang. Rasio yang digunakan untuk mengukur leverage adalah Dept To Equity Ratio $($ DER $)=$ Total Hutang $:$ Total ekuitas.

\subsubsection{Rasio Aktivitas}

Rasio aktivitas menunjukan tingkat efisiensi pengunaan keseluruhan aktiva perusahaan dalam menghasilkan volume penjualan tertentu. Rasio ini menggunakan rumus : total asstes turn over $($ TATO $)=$ Penjualan : total aktiva.

\subsubsection{Manajemen Laba}

Manajemen laba dalam penelitian ini sebagai Varabel intervening. Manajemen laba dalam penelitian ni diukur dengan menggunakan Model Healy. Model yang digunakan adalah estimasi akrual kelolaan, pada model ini diasumsikan akrual non kelolaan pada periode $t$ dperkirakan 0. Estmasi kelolaan 
distandarisasi dengan total aset dengan maksud untuk mengantisipasi distorsi ukuran perusahaan, Arif (2012). Pengukuran estimasi akrual kelolaan menggunakan model Healy dalam Arif (2012) =adalah sebagai berikut :

$$
=\longdiv { - 1 }
$$

\subsubsection{Rating Obligasi}

Dalam penelitian ini rating obligasi diukur menggunakan interpretasi dari penelitian Sari (2010) dalam Arif (2012) yang menggunakan kode 18 sampai dengan 1. Dengan maksud bobot yang tinggi yang lebih mereprentasikan peringkat yang lebih tinggi.

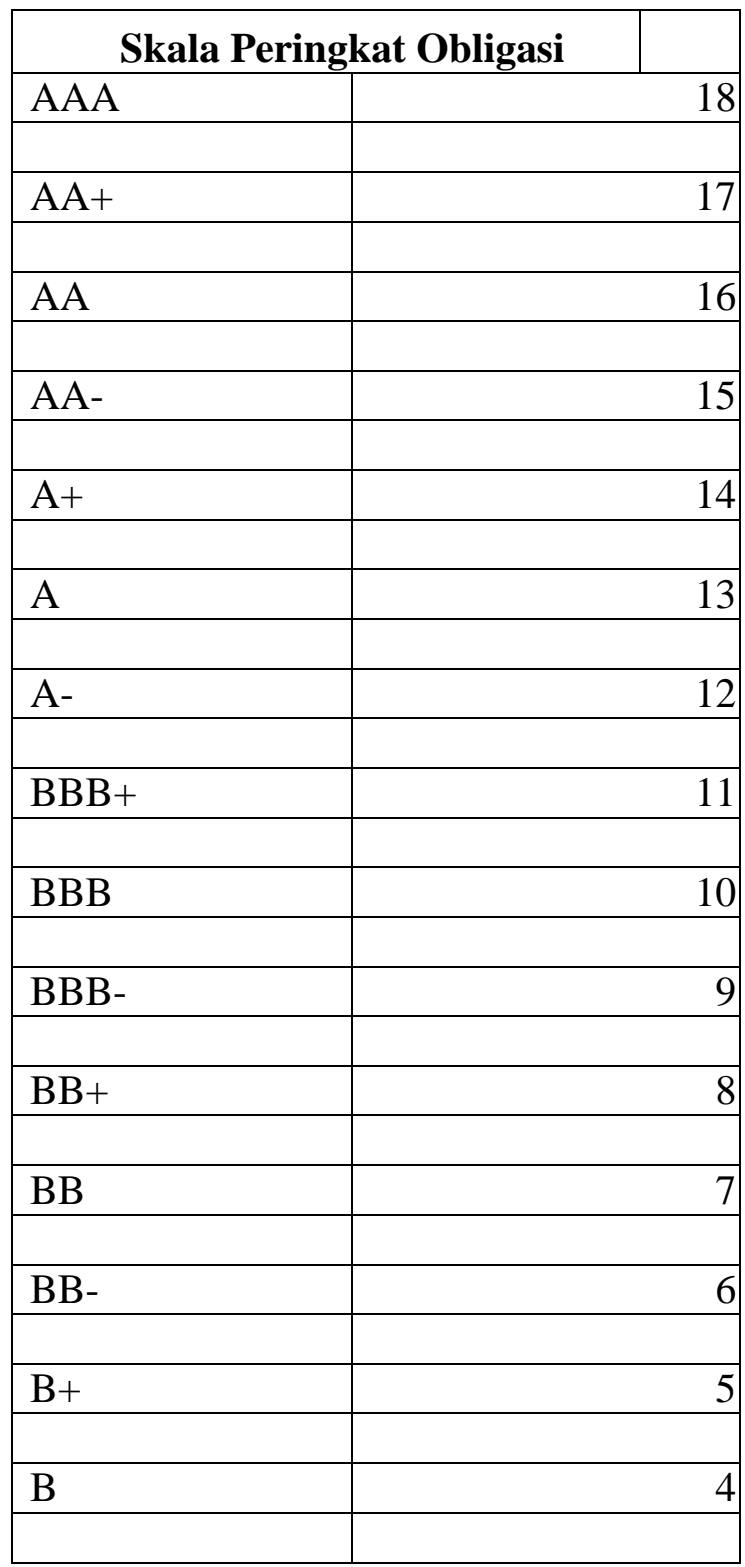




\begin{tabular}{|l|r|}
\hline B- & 3 \\
\hline & 2 \\
\hline CCC & 1 \\
\hline & \\
\hline D & \\
\hline &
\end{tabular}

\subsection{Teknik Analisis}

Penelitian ini menggunakan uji hipotesis dan regresi dengan program SPSS 23 tahun 2015

\section{ANALISIS HASIL}

\subsection{Statistik Deskriptif}

Sampel pada penelitian ini adalah 6 perusahaan manufaktur yang telah lolos dari kriteria penelitian pada populasi 144 perusahaan manufaktur yang terdaftar di BEI selama 11 tahun (2005 - 2015). Statistik Deskriptif meninjukan nilai minium, maximum, mean dan standar deviation. Penelitian ini memberikan gambaran tentang perusahaan manufaktur yang di teliti dalam keadaan yang kurang baik, bisa di lihat dari mean profitabilitas 1,5 kali yang artinya perusahaan mampu mendapatkan laba 0,5 kali lipat, mean dari likuiditas 1,4 kali yang artinya aktiva lancar perusahaan lebih besar 0,4 kali lipat dari hutang lancarnya, sedangkan mean dari leverage 1,6 kali yang artinya aktivitas perusahaan di biayai oleh hutang lebih besar dari modal sendiri sebanyak 0,6 kali lipat, dan mean dari aktivitas 0,98 kali yang artinya penjulan perusahaan lebih kecil dari asset yang dimiliki perusahaan, dari kinerja keuangan perusahaan manufaktur yang telah dijabarkan oleh ROCE, CR, DER, dan TATO dapat di katakana kurang baik, dapat di lihat dari perbandingan antara laba yang di hasilkan sebesar 0,5 kali lipat, dan aktiva lancar 0,4 kali lipat dari hutang lancarnya di kategorikan perusahaan yang dalam keadaan baik, tetapi dilihat dari aktivitas perusahaan yang di biayai oleh hutang sebanyak 0,6 kali lipat dan penjualan yang tidak lebih besar dari total aktiva yang di miliki perusahaan, maka perusahaan manufaktur dapat dikatakan kurang baik. Dari sisi Rating Obligasi memiliki nilai rata - rata 13 yang berada pada skala A. Skala A dapat di artikan, bagi para kreditur di sarankan oleh PT.Pefindo untuk menyalurkan datanya dalam obligasi perusahaan tersebut. Dari sisi Manajemen Laba, nilai rata - rata -0,0038, memperlihatkan bahwa manufaktur menggunakan manajemen laba dengan menurunkan nilai dari akun akun di laporan keuangan. 


\subsection{Analisis Regresi Persamaan 1}

Persamaan $1: \mathrm{Z}(\mathrm{EM}): \alpha+\beta 1 \mathrm{ROCE}+\beta 2 \mathrm{CR}+\beta 3 \mathrm{BER}+\beta 4 \mathrm{TATO}+\varepsilon^{1}$.

UJi Statistik F

\begin{tabular}{|l|r|r|r|c|c|}
\hline Model & Sum of Squares & Df & Mean Square & F & Sig. \\
\hline Regression &, 131 & 4 &, 033 & 8,524 &, $000^{\mathrm{b}}$ \\
Residual &, 234 & 61 &, 004 & & \\
Total &, 365 & 65 & & & \\
\hline
\end{tabular}

Uji Koefisien Determinasi

\begin{tabular}{|l|r|r|r|r|}
\hline Model & \multicolumn{1}{l|}{ R } & R Square & Adjusted R Square & Std. Error of the Estimate \\
\hline 1 &, 59 & & & \\
& $9 \mathrm{a}$ &, 359 &, 316 &, 06198 \\
\hline
\end{tabular}

\subsubsection{PENGUJIAN HIPOTESIS 1 : Diduga ROCE, CR, DER, TATO} berpengaruh simultan positif terhadap Manajemen Laba.

Hipotesis 1 penelitian ini menyatakan bahwa ROCE, CR, DER, TATO berpengaruh positif dan signifikan terhadap Manajemen Laba. Output SPSS 23 koefisien determinasi yang ditunjukan dari nilai Adjusted R Square sebesar 0,316 Dan dengan nilai uji $\mathrm{F}$ hitung di bandingan dengan nilai $\mathrm{F}$ tabel, dimana $\mathrm{F}$ hitung yang di peroleh sebesar $F=8,524$ lebih besar ( $>$ ) dari $F$ tabel sebesar 2,5252, dengan nilai tersebut variable ROCE, CR, DER, TATO secara bersama - sama mempengaruhi simultan positif dan signifikan terhaadap Manajemen Laba. Dengan demikian hipotesis 1 di terima. Hal ini menunjukan bahwa implementasi Kinerja keuangan mempengaruhi manajemen laba dikarenakan Salah satu ukuran kinerja perusahaan yang sering digunakan sebagai dasar pengambilan keputusan bisnis adalah laba yang dihasilkan perusahaan, merupakan unsur utama dalam laporan keuangan dan sangat penting bagi pihak-pihak yang menggunakannya karena memiliki nilai prediktif. Hal tersebut membuat manajemen perusahaan untuk melakukan manajemen laba agar kinerja perusahaan tampak baik dilihat dari pihak eksternal.

Uji Statistik t

\begin{tabular}{|l|r|r|r|r|r|}
\hline & \multicolumn{2}{|c|}{ Unstandardized } & Standardized & & \\
\cline { 2 - 4 } & \multicolumn{1}{|c|}{ B } & Std. Error & Beta & & \\
\hline (Constant) &,- 035 &, 032 & & $-1,115$ &, 269 \\
ROCE_X1 &,- 020 &, 011 &,- 245 & $-1,839$ &, 071 \\
CR_X2 &,- 031 &, 015 &,- 261 & $-2,135$ &, 037 \\
DER_X3 &, 033 &, 010 &, 356 & 3,430 &, 001 \\
TATO_X4 &, 057 &, 023 &, 282 & 2,451 &, 017 \\
\hline
\end{tabular}




\subsubsection{PENGUJIAN HIPOTESIS 2 : Diduga ROCE, berpengruh positif dan signifikan terhadap Manajemen Laba.}

Pengujian ini bertujuan untuk mengetahui pengaruh ROCE secara parsial terhadap manajemen laba. Koefisien regresi ROCE adalah -0,245. Hal ini menunjukkan ROCE mempunyai pengaruh negatif terhadap Manajemen Laba. Nilai signifikansi pengujian menunjukkan lebih besar dari 0.05 yaitu sebesar 0,071. artinya bahwa variasi variable ROCE secara parsial tidak mempunyai pengaruh yang signifikan terhadap Manajemen Laba hal tersebut diperkuat dengan Nilai $t$ hitung yang lebih kecil dari nilai t tabel $(-1,839 \leq 1,999)$. Dengan demikian hipotesis 2 di tolak. Profitabilitas mengukur tingkat keuntungan yang dihasilkan oleh perusahaan. Profitabilitas adalah kemampuan perusahaan untuk memperoleh laba dari kegiatan bisnis yang dilakukannya (Ghost,et. Al., 2000). Profitabilitas mencakup seluruh pendapatan dan biaya yang dikeluarkan oleh perusahaan sebagai penggunaan aktiva dan pasiva dalam suatu periode. Investor menggunakan profitabilitas untuk memprediksi seberapa besar penggunaan nilai atas saham yang dimiliki.

Untuk mengukur tingkat profitabilitas perusahaan dapat dilakukan dengan menggunakan rasio profitabilitas. Rasio ini memberikan gambaran mengenai perubahan finansial perusahaan dari tahun ke tahun. Rasio profitabilitas merupakan rasio yang mengukur kemampuan perusahaan dalam menghasilkan laba. Pengukuran efisiensi untuk menghasilkan laba dalam penelitian ini menggunakan rasio return on common equity (ROCE) diukur dengan Laba Kotor dibagi dengan rata-rata Total Aktiva di kurangi Total hutang di kurangi saham preferen. Hasil diatas menunjukan bahwa perusahaan tidak mengaplikasikan Manajemen Laba di dalam laporan keuangan yang dapat di lihat profitabilitas dari alat ukur ROCE dimana laba bersih, total akiva dan hutang tidak mungkin bisa di manajemen labakan secara bersama - sama, atau dengan kata lain, jika perusahaan menaikan aktiva dan atau menurunkan hutang baik secara bersama sama atau tidak bersama - sama maka akan memberikan efek kecilnya rasio ROCE. Hasil penelitian ini mendukung penelitian yang dilakukan oleh gunawan dan darmawan (2015) yang menyatakan profitabilitas tidak berpengaruh terhadap manajemen laba.

\subsubsection{PENGUJIAN HIPOTESIS 3 : Diduga CR, berpengaruh positif dan signifikan terhadap Manajemen Laba.}

Pengujian ini bertujuan untuk mengetahui pengaruh Current Ratio (CR) secara parsial terhadap Manajemen Laba. Koefisien regresi CR adalah -0,261. Hal ini menunjukkan CR mempunyai pengaruh negatif terhadap Manajemen Laba. Nilai signifikansi pengujian menunjukkan lebih kecil dari 0.05 yaitu sebesar 0.037. artinya bahwa variasi variable CR secara parsial mempunyai pengaruh yang signifikan terhadap Manajemen Laba hal tersebut diperkuat dengan Nilai t 
hitung yang lebih besar dari nilai t tabel $(2,135>1,999)$. Dengan demikian hipotesis 3 di terima. Likuiditas untuk mengetahui kemampuan perusahaan dalam memenuhi kewajibannya. Dalam penelitian ini Current Ratio (CR) digunakan untuk mengukur kemampuan perusahaan dalam membayar kewajiban jangka pendek atau hutang yang segera jatuh tempo. Dengan kata lain, seberapa banyak aktiva lancar yang tersedia untuk menutupi kewajiban jangka pendek yang segera jatuh tempo. Rasio ini juga dapat dikatakan sebagai bentuk untuk mengukur tingkat keamanan suatu perusahaan. Dalam praktiknya sering kali dipakai bahwa rasio lancar dengan standar 200\% (2:1) yang terkadang sudah dianggap sebagai ukuran yang cukup baik atau memuaskan bagi suatu perusahaan. Artinya dengan hasil rasio seperti itu, perusahaan sudah merasa berada di titik aman dalam jangka pendek. Dengan ketentuan rasio likuiditas diatas, dapat di ketahui perusahaan mengaplikasikan manajemen laba dengan menaikan aktiva lancar atau menurunkan hutang lancar yang dilakukan tidak secara bersama -sama di dalam laporan keuangan.

Hasil penelitian ini mendukung penelitian yang dilakukan oleh Rika Ambarwati (2016) yang menyatakan Likuiditas berpengaruh terhadap manajemen laba.

\subsubsection{PENGUJIAN HIPOTESIS 4 : Diduga DER, berpengaruh positif dan signifikan terhadap Manajemen Laba.}

Pengujian ini bertujuan untuk mengetahui pengaruh Debt Equity Ratio (DER) secara parsial terhadap Manajemen Laba. Koefisien regresi DER adalah 0,356. Hal ini menunjukkan DER mempunyai pengaruh positif terhadap Manajemen Laba. Nilai signifikansi pengujian menunjukkan lebih kecil dari 0.05 yaitu sebesar 0.001. artinya bahwa variasi variable DER secara parsial mempunyai pengaruh positif yang signifikan terhadap Manajemen Laba hal tersebut diperkuat dengan Nilai thitung yang lebih besar dari nilai t tabel $(3,430 \geq$ 1,999). Dengan demikian hipotesis di terima.

Laverage digunakan untuk menggambarkan suatu keadaan atau kemampuan perusahaan dalam memepergunakan aktiva atau dana yang mempunyai beban tetap untuk memperbesar tingkat penghasilan bagi pemilik perusahaan. Leverage menunjukkan berapa banyak hutang yang digunakan utnuk membiayai asset - asset perusahaan. Rasio laverage dalam penelitian ini menggunakan Debt Equity Ratio (DER) yaitu perbandingan hutang dan aktiva. Semakin besar hutang suatu perusahaan dibandingkan dengan aktivanya, maka semakin besar resiko yang dihadapi oleh perusahaan untuk membayar kewajibannya. Semakin besar rasio leverage menunjukkan semakin besar tingkat ketergantungan perusahaan terhadap pihak eksternal (kreditur) dan semakin besar pula beban biaya hutang (biaya Bunga) yang harus dibayar oleh perusahaan. 
Dengan semakin meningkatnya rasio leverage (dimana beban hutang juga semakin besar) maka hal tersebut berdampak terhadap profitabilitas yang diperoleh perusahaan karena sebagian digunakan untuk membayar bunga pinjaman. Dengan semakin tingginya tingkat hutang yang dimiliki perusahaan, hal tersebut memungkinkan manajemen untuk melakukan manipulasi laba untuk meningkatkan citra perusahaan dimata masyarakat dan agar investor tetap mau berinvestasi di perusahaan tersebut. Dari keterangan DER tersebut dapat di indikasikan perusahaan melakukan manajemen laba guna memberikan efek terbaik bagi para kreditur dan atau calon kreditur dimana jika perusahaan menurunkan hutang atau menaikan equity secara tidak bersama - sama, maka akan menghasilakn rasio DER yang di inginkan.

Penelitian ini mendukung penelitian yang dilakukan oleh Subhan (2010) yang menyatakan leverage berpengaruh positif terhadap manajemen laba.

\subsubsection{PENGUJIAN HIPOTESIS 5 : Diduga TATO berpengaruh positif dan signifikan terhadap Manajemen Laba.}

Pengujian ini bertujuan untuk mengetahui pengaruh Total Asset Turn Over (TATO) secara parsial terhadap Manajemen Laba. Koefisien regresi TATO adalah 0,282. Hal ini menunjukkan TATO mempunyai pengaruh positif terhadap Manajemen Laba. Nilai signifikansi pengujian menunjukkan lebih besar dari 0.05 yaitu sebesar 0.017. artinya bahwa variasi variable TATO secara parsial mempunyai pengaruh negatif yang tidak signifikan terhadap Manajemen Laba hal tersebut diperkuat dengan $(2,451 \leq 1,999)$. Dengan demikian hipotesis 5 dapat di terima. Rasio aktivitas adalah rasio yang mengukur seberapa efektif perusahaan dalam memanfaatkan semua sumber daya yang ada padanya. Semua rasio aktivitas ini melibatkan perbandingan antara tingkat penjualan dan investasi pada berbagai jenis aktiva. Rasio-rasio aktivitas menganggap bahwa sebaiknya terdapat keseimbangan yang layak antara penjualan dan beragam unsur aktiva misalnya persediaan, aktiva tetap dan aktiva lainnya. Aktiva yang rendah pada tingkat penjualan tertentu akan mengakibatkan semakin besarnya dana kelebihan yang tertanam pada aktiva tersebut. Dana kelebihan tersebut akan lebih baik bila ditanamkan pada aktiva lain yang lebih produktif. Dengan kata lain, pada penelitian ini perusahaan mengaplikasikan manajemen laba pada laporan keuangan yang dapat dilihat pada rasio aktivitas dengan mengunakan alat ukur TATO diamana ketika perusahaan menaikan atau menurunkan aktiva dan penjualan secara bersama - sama atau tidak secara bersama - sama akan mendapatkan rasio TATO yang di inginkan. 
4.3 Analisis Regresi Persamaan 2.

Persamaan 2 : Y(RO): $\alpha+\beta 1$ ROCE+ $+\beta 2 C R+\beta 3 D E R+\beta 4 T A T O+\beta 5 E M+\varepsilon^{2}$

Uji Statistik F

\begin{tabular}{|l|r|r|r|r|l|}
\hline Model & Sum of Squares & df & Mean Square & F & Sig. \\
\hline Regression & 84,781 & 5 & 16,956 & 6,175 &, $000^{\mathrm{b}}$ \\
Residual & 164,749 & 60 & 2,746 & & \\
Total & 249,530 & 65 & & & \\
\hline
\end{tabular}

Uji Koefisien Determinasi

\begin{tabular}{|c|c|r|r|r|}
\hline Model & $\mathrm{R}$ & $\mathrm{R}$ Square & Adjusted R Square & Std. Error of the Estimate \\
\hline 1 &, $583^{\mathrm{a}}$ &, 340 &, 285 & 1,65705 \\
\hline
\end{tabular}

4.3.1 PENGUJIAN HIPOTESIS 6 : Diduga ROCE, CR, DER, TATO, dan Manajemen Laba berpengaruh simultan positif dan signifikan terhadap Rating Obligasi.

Hipotesis 6 penelitian ini menyatakan bahwa ROCE, CR, DER, TATO dan manajemen laba berpengaruh positif dan signifikan terhadap Rating Obligasi. Output SPSS 23 nilai dari Adjusted R Square sebesar 0,285 variasi Rating Obligasi dapat dijelaskan oleh ROCE, CR, DER, TATO dan manajemen laba sedangkan sisanya dipengaruhi oleh variable lain yang tidak di terliti dalam penelitian ini. Dengan nilai uji $\mathrm{F}$ hitung di bandingan dengan nilai $\mathrm{F}$ tabel, dimana F hitung yang di peroleh dari output SPSS 23 tabel 4.3.1. sebesar F = 6,175 lebih besar (>) dari F tabel sebesar 2,3683. Dengan nilai tersebut variable ROCE, CR, DER, TATO dan Manajemen Laba secara bersama - sama mempengaruhi simultan positif dan signifikan terhaadap Rating Obligasi. Dengan demikian hipotesis 6 yang menyatakan ROCE, CR, DER, TATO di terima.

Uji Statistik $\mathbf{t}$

\begin{tabular}{|l|r|r|r|r|r|}
\hline & \multicolumn{2}{|c|}{$\begin{array}{c}\text { Unstandardized } \\
\text { Coefficients }\end{array}$} & $\begin{array}{c}\text { Standardized } \\
\text { Coefficients }\end{array}$ & & \\
\cline { 2 - 4 } Model & \multicolumn{1}{|c|}{$\mathrm{B}$} & Std. Error & \multicolumn{2}{c|}{ Beta } & \multicolumn{1}{c|}{ Sig. } \\
\hline (Constant) & 14,223 &, 856 & & 16,617 &, 000 \\
ROCE_X1 & 1,201 &, 292 &, 576 & 4,116 &, 000 \\
CR_X2 &, 289 &, 405 &, 092 &, 713 &, 478 \\
DER_X3 &,- 442 &, 282 &,- 182 & $-1,568$ &, 122 \\
TATO_X4 & $-2,270$ &, 652 &,- 429 & $-3,483$ &, 001 \\
EM_Z & 1,014 &, 423 &, 515 & 2,880 &, 022 \\
\hline
\end{tabular}




\subsubsection{PENGUJIAN HIPOTESIS 7 : Diduga ROCE berpengaruh positif dan signifikan terhadap Peringkat Obligasi.}

Pengujian ini bertujuan untuk mengetahui pengaruh ROCE secara parsial terhadap peringkat obligasi. Koefisien regresi ROCE adalah 0,576 Hal ini menunjukkan ROCE mempunyai pengaruh positif terhadap peringkat obligasi. Nilai signifikansi pengujian menunjukkan lebih kecil dari 0.05 yaitu sebesar 0.000 artinya bahwa variasi variable ROCE secara parsial mempunyai pengaruh positif dan signifikan terhadap Rating Obligasi hal tersebut diperkuat dengan nilai $\mathrm{t}$ hitung yang lebih besar dari nilai t tabel $(4,116>2,000)$. Dengan demikian hipotesis 7 di terima. Profitabilitas digunakan untuk mengukur kemampuan perusahaan menghasilkan laba dan juga untuk mengetahui efektifitas perusahaan dalam mengelola sumber-sumber yang dimilikinya. Apabila laba perusahaan tinggi maka akan memberikan peringkat obligasi yang naik pula sehingga variabel ini dikatakan dapat mempengaruhi prediksi peringkat obligasi. ROCE menggambarkan EBIT yang di bagi dengan rat-rata total aktiva dikurangi total hutang dan dikurangi dengan saham preferen, dimana ketika EBIT memiliki nilai yang besar, pasti akan berpengaruh terhadap rating obligasi.

Penelitian ini mendukung penelitian yang dilakukan oleh Damayanti dan Fitriyah (2013) Daljono (2011) yang menyatakan Profitabilitas berpengaruh positif terhadap rating obligasi.

\subsubsection{PENGUJIAN HIPOTESIS 8 : Diduga CR berpengaruh positif dan signifikan terhadap Peringkat Obligasi.}

Pengujian ini bertujuan untuk mengetahui pengaruh CR secara parsial terhadap peringkat obligasi. Koefisien regresi CR adalah 0,092 Hal ini menunjukkan CR mempunyai pengaruh positif terhadap peringkat obligasi. Nilai signifikansi pengujian menunjukkan lebih besar dari 0.05 yaitu sebesar 0.478 artinya bahwa variasi variable DER secara parsial tidak berpengaruh signifikan terhadap rating obligasi hal tersebut diperkuat dengan Nilai t hitung yang lebih kecil dari nilai $t$ tabel $(0,713<2,000)$. Dengan demikian hipotesis 8 tidak dapat di terima. Likuiditas berhubungan dengan masalah kemampuan suatu perusahaan untuk memenuhi kewajiban finansialnya yang akan segera harus dipenuhi. Jumlah alat-alat pembayaran (alat-alat likuid) yang dimiliki oleh perusahan pada suatu saat merupakan kekuatan membayar dari perusahaan bersangkutan. Suatu perusahaan yang mempunyai "kekuatan membayar" belum tentu dapat memenuhi segala kewajiban finansialnya yang harus segera dipenuhi, atau dengan kata lain perusahaan tersebut tentu mempunyai kemampuan membayar Bambang Riyanto (2001). Dengan demikian Rating obligasi bersangkutan dengan bagaimana perusahaan dapat memenuhi kewajibanya tepat sebelum masa tenggangnya 
hutang tersebut, jika perusahaan dianggap tidak mampu memenuhi kewajban jangka pendeknya.

Penelitian ini mendukung penelitian yang dilakukan oleh Estiyanti dan Yasa (2012) yang menyatakan Leverage tidak berpengaruh positif terhadap rating obligasi.

\subsubsection{PENGUJIAN HIPOTESIS 9 : Diduga DER berpengaruh positif dan signifikan terhadap Peringkat Obligasi.}

Pengujian ini bertujuan untuk mengetahui pengaruh DER secara parsial terhadap peringkat obligasi. Koefisien regresi DER adalah -0,182. Hal ini menunjukkan DER mempunyai pengaruh negatif terhadap peringkat obligasi. Nilai signifikansi pengujian menunjukkan lebih besar dari 0.05 yaitu sebesar 0.122 artinya bahwa variasi variable DER secara parsial tidak berpengaruh signifikan terhadap rating obligasi hal tersebut diperkuat dengan Nilai t hitung yang lebih kecil dari nilai $t$ tabel $(-1,568 \leq 2,000)$. Dengan demikian hipotesis 9 di tolak. Leverage suatu perusahaan dapat menunjukkan kemampuannya untuk memenuhi segala kewajiban finansial baik jangka panjang maupun jangka pendek pada saat perusahaan itu dilikuidasi (Linandarini dan Pamudji, 2010). Rasio DER yang di ukur dengan menggunakan hutang di bagi modal sendiri dianggap tidak dapat mewakilkan rating obligasi, dikarenakan keseluruhan hutang yang besar merupakan kewajiban yang harus dipenuhi oleh perusahaan tepat pada waktunya. Penelitian yang dilakukan oleh Linandarini dan Pamudji (2010) dan Sari (2007) menghasilkan bahwa Leverage tidak memiliki kemampuan untuk memprediksi peringkat obligasi.

\subsubsection{PENGUJIAN HIPOTESIS 10 : Diduga TATO berpengaruh positif dan signifikan terhadap Peringkat Obligasi.}

Pengujian ini bertujuan untuk mengetahui pengaruh TATO secara parsial terhadap peringkat obligasi. Koefisien regresi TATO adalah $-0,429$. Hal ini menunjukkan TATO mempunyai pengaruh negatif terhadap peringkat obligasi. Nilai signifikansi pengujian menunjukkan lebih kecil dari 0.05 yaitu sebesar 0.001 . Artinya bahwa variasi variable TATO secara parsial mempunyai pengaruh yang signifikan terhadap peringkat obligasi hal tersebut diperkuat dengan Nilai $t$ hitung yang lebih besar dari nilai t tabel $(3,483>2,000)$. Dengan demikian hipotesis 10 di terima. Perusahaan dengan tingkat aktivitas yang tinggi cenderung akan mampu menghasilkan pendapatan yang lebih tinggi dibandingkan perusahaan dengan tingkat aktivitas yang rendah. Rasio aktivitas secara signifikan berpengaruh positif terhadap peringkat obligasi. Apabila aktivitas perusahaan tinggi, maka kemungkinan besar obligasi perusahaannya masuk investment grade, karena dengan penjualan yang tinggi cenderung lebih mampu menghasilkan laba 
yang tinggi, sehingga perusahaan mampu memenuhi segala kewajibannya kepada para investor secara lebih baik.

Hasil penelitian Raharja dan Sari (2008) menghasilkan bahwa rasio aktivitas memiliki kemampuan untuk memprediksi peringkat obligasi.

\subsubsection{PENGUJIAN HIPO6TESIS 11 : Diduga Manajemen Laba berpengaruh positif dan signifikan terhadap Peringkat Obligasi. \\ Pengujian ini bertujuan untuk mengetahui pengaruh Manajemen Laba} secara parsial terhadap peringkat obligasi. Koefisien regresi Manajemen Laba adalah 0,515. Hal ini menunjukkan Manajemen Laba mempunyai pengaruh positif terhadap peringkat obligasi. Nilai signifikansi pengujian menunjukkan lebih kecil dari 0.05 yaitu sebesar 0,022. artinya bahwa variasi variable Manajemen Laba secara parsial mempunyai pengaruh yang signifikan terhadap peringkat obligasi hal tersebut diperkuat dengan Nilai $\mathrm{t}$ hitung yang lebih besar dari nilai $\mathrm{t}$ tabel $(2,880>2,000)$. Dengan demikian hipotesis 11 di terima. Manajemen laba adalah tindakan-tindakan manajer untuk menaikan (menurunkan) laba periode berjalan dari sebuah perusahaan yang dikelola untuk tujuan menghindari kerugian dan lain sebagainya. Manajemen laba dapat mempengaruhi peringkat obligasi perusahaan. Sesuai dengan teori agensi manajemen yang melakukan proses manajemen laba menginginkan laba perusahaan terlihat baik agar dapat mempengaruhi peringkat obligasi berada pada kondisi investment grade. Peringkat obligasi itu sendiri merupakan hasil penilaian yang dilakukan oleh perusahaan pemeringkat mengenai efek utang suatu perusahaan. Peringkat obligasi suatu perusahaan dapat dipengaruhi oleh manajemen laba dengan cara yang sama dengan emisi obligasi yaitu menaikkan laba sebuah perusahaan sehingga kinerja perusahaan terlihat baik di mata kreditur dan kreditur pada akhirnya mempercayakan memberikan utang kepada perusahaan. Jika kinerja perusahaan terlihat baik dan banyak kreditur yang mempercayakan dananya terhadap perusahaan maka lembaga pemeringkat akan memberikan peringkan obligasi yang baik pula terhadap perusahaan tersebut.

Penelitian ini mendukung penelitian yang dilakukan oleh Wisnu Arif (2012) yang menyatakan manajemen laba tidak berpengaruh terhadap rating obligasi.

\subsection{Analisis Jalur (Path Analysis).}

Dengan ketentuan sebagai berikut:

1. Jika nilai uji Path atau jalur secara langsung > tidak langsung maka variabel Manajemen Laba tidak intervening atau tidak memediasi.

2. Jika nilai uji Path atau jalur secara langsung < secara langsung maka variabel Manajemen Laba intervening atau memediasi.

Berikut hasil uji Path Analysis yang sudah dilakukan dan ditunjukkan dengan gambar dibawah ini : 


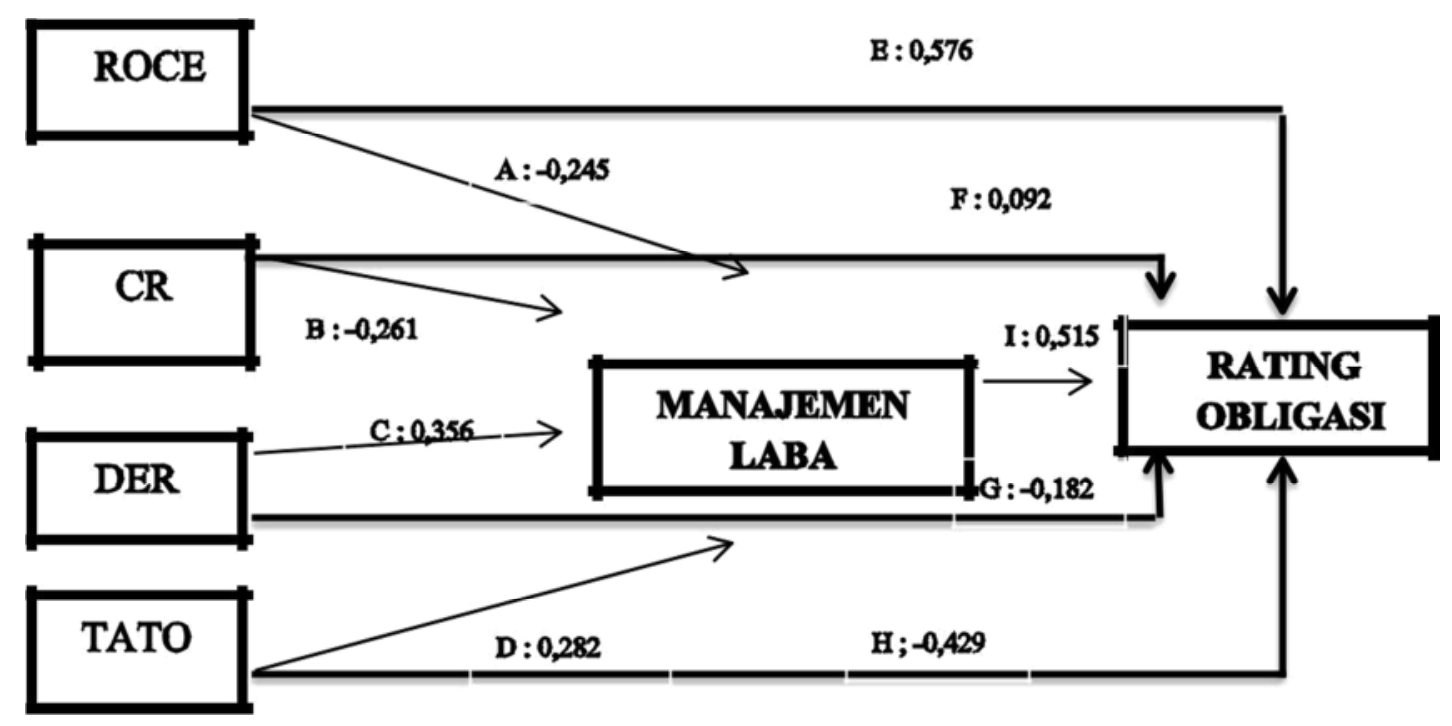

\subsubsection{Pengaruh variable ROCE terhadap variable Rating Obligasi melalui atau tidak melalui variable Manajemen Laba. \\ Pengaruh secara langsung variabel ROCE terhadap variabel Rating} Obligasi memiliki nilai sebesar 0,576 sedangkan pengaruh secara tidak langsung variabel ROCE melalui variabel Manajemen Laba memiliki nilai sebesar -0,245. Dengan perhitungan sebagai berikut:

$$
\begin{array}{ll}
\text { Pengaruh secara langsung } & =0,576 \\
\text { Pengaruh secara tidak langsung } & =-0,245 \times 0,515=-0,126
\end{array}
$$

Yang artinya pengaruh secara langsung > secara tidak langsung $(0,576>-0,126)$. Sehingga variabel Manajemen Laba tidak Intervening atau tidak memediasi variabel ROCE.

\subsubsection{Pengaruh variable CR terhadap variable Rating Obligasi melalui atau tidak melalui variable Manajemen Laba.}

Pengaruh secara langsung variabel CR terhadap variabel Rating Obligasi memiliki nilai sebesar 0,049 sedangkan pengaruh secara tidak langsung variabel CR melalui variabel Manajemen Laba memiliki nilai sebesar -0,261. Dengan perhitungan sebagai berikut:

$$
\begin{array}{ll}
\text { Pengaruh secara langsung } & =0,092 \\
\text { Pengaruh secara tidak langsung } & =-0,261 \times 0,515=-0,134
\end{array}
$$

Yang artinya pengaruh secara langsung > secara tidak langsung $(0,092>-0,134)$. Sehingga variabel Manajemen Laba tidak Intervening atau tidak memediasi variabel CR.

\subsubsection{Pengaruh variable DER terhadap variable Rating Obligasi melalui atau tidak melalui variable Manajemen Laba. \\ Pengaruh secara langsung variabel DER terhadap variabel Rating Obligasi memiliki nilai sebesar $-0,182$ sedangkan pengaruh secara tidak langsung variabel}


DER melalui variabel Manajemen Laba memiliki nilai sebesar 0,356. Dengan perhitungan sebagai berikut:

Pengaruh secara langsung $\quad=-0,182$

Pengaruh secara tidak langsung $=0,356 \times 0,515=0,183$

Yang artinya pengaruh secara langsung < secara tidak langsung $(-0,182<0,183)$.

Sehingga variabel Manajemen Laba Intervening atau memediasi variabel DER.

\subsubsection{Pengaruh variable TATO terhadap variable Rating Obligasi melalui} atau tidak melalui variable Manajemen Laba.

Pengaruh secara langsung variabel TATO terhadap variabel Rating Obligasi memiliki nilai sebesar -0,429 sedangkan pengaruh secara tidak langsung variabel DER melalui variabel Manajemen Laba memiliki nilai sebesar 0,282. Dengan perhitungan sebagai berikut:

Pengaruh secara langsung $\quad=-0,429$

Pengaruh secara tidak langsung $=0,282 \times 0,515=0,145$

Yang artinya pengaruh secara langsung < secara tidak langsung $(-0,429<0,145)$.

Sehingga variabel Manajemen Laba Intervening atau memediasi variabel TATO.

\subsubsection{Pengaruh variable ROCE, CR, DER dan TATO terhadap variable} Rating Obligasi melalui atau tidak melalui variable Manajemen Laba. Sedangkan perbandingan perhitungan antara pengaruh secara langsung variabel ROCE, CR, DER dan TATO terhadap variabel Rating Obligasi dibandingkan dengan pengaruh secara tidak langsung melalui variabel Manajemen Laba memiliki perhitungan sebagai berikut:

Pengaruh secara langsung $=0,576+0,092+(-) 0,182+(-) 0,429=$ 0,057 Pengaruh secara tidak langsung $=(-0,245 \times 0,515)+(-$ $0,261 \times 0,515)+$

$$
\begin{aligned}
& (0,356 \times 0,515)+ \\
& (0,282 \times 0,515) \\
& =0,068
\end{aligned}
$$

Yang artinya pengaruh secara langsung < pengaruh secara tidak langsung yaitu $(0,057<0,068)$. Berdasarkan hasil penelitian diperoleh bahwa Manajemen Laba merupakan variabel intervening antara ROCE, CR, DER dan TATO secara simultan terhadap Rating Obligasi.

\subsection{Hasil Penelitian}

Dari analisis diperoleh hasil regresi sebagai berikut :

\subsubsection{Persamaan $1:($ EM $)=-0,245 R O C E-0,261 C R+0,356 D E R+0,282$ TATO $+\varepsilon^{1}$.}

Dari persamaan diatas, maka dapat dijelaskan bahwa : 
1. Koefisien ROCE sebesar -0,245 artinya jika ROCE naik sebesar $1 \%$ maka Manajemen laba akan turun sebesar 24,5\% dengan asumsi variablevariabel lain tetap.

2. Koefisien CR sebesar -0,261 artinya jika CR naik sebesar $1 \%$ maka Manajemen laba akan turun sebesar 26,1\% dengan asumsi variablevariabel lain tetap.

3. Koefisien DER sebesar 0,356 artinya jika DER naik sebesar $1 \%$ maka Manajemen laba akan naik sebesar 35,6\% dengan asumsi variablevariabel lain tetap.

4. Koefisien TATO sebesar 0,282 artinya jika TATO naik sebesar $1 \%$ maka Manajemen laba akan naik sebesar 28,2\% dengan asumsi variablevariabel lain tetap.

\subsubsection{Persamaan $2:(\mathrm{RO})=0,576 \mathrm{ROCE}+0,092 \mathrm{CR}-0,182 \mathrm{DER}-0,429 \mathrm{TATO}$ $+0,515 \mathrm{EM}+\varepsilon^{2}$}

Dari persamaan diatas, maka dapat dijelaskan bahwa :

1. Koefisien ROCE sebesar 0,576 artinya jika ROCE naik sebesar $1 \%$ maka Rating Obligasi akan naik sebesar 57,6\% dengan asumsi variable-variabel lain tetap.

3. Koefisien CR sebesar 0,092 artinya jika CR naik sebesar 1\% maka Rating Obligasi akan naik sebesar 9,2\% dengan asumsi variable-variabel lain tetap.

4. Koefisien DER sebesar -0,182 artinya jika DER naik sebesar $1 \%$ maka Rating Obligasi akan turun sebesar 18,2\% dengan asumsi variablevariabel lain tetap.

5. Koefisien TATO sebesar -0,429 artinya jika TATO naik sebesar $1 \%$ maka Rating Obligasi akan turun sebesar 42,9\% dengan asumsi variablevariabel lain tetap.

6. Koefisien Manajemen laba sebesar 0,515 artinya jika Manajemen Laba naik sebesar $1 \%$ maka Rating Obligasi akan naik sebesar 51,5\% dengan asumsi variable-variabel lain tetap.

\subsubsection{Temuan Penelitian}

Kinerja keuangan merupakan jantung dari perusahaan dimana setiap kegiatan di dalam peerusahaan akan mempertimbangkan segala hal dan menyangkutkanya dengan kinerja keuangan, dengan demikian perusahaan akan membuat kinerja keuangan jauh lebih baik. Peringkat obligasi merupakan ekspektasi agen pemeringkatan terhadap penualan, laba dan arus kas perusahaan. Informasi yang terkandung dalam peringkat obligasi menunjukan kemampuan suatu perusahaan untuk membayar kewajiban. Perusahaan tentunya ingin mendapatkan peringkat yang tinggi untuk mempengaruhi persepsi investor dan 
kreditur misalnya dengan cara melakukan manajemen laba. Secara teori, kemampuan laba merupakan salah satu variabel yang dapat mempengaruhi motivasi manajer untuk melakukan manajemen laba. (Gumanti dan Singgih, 2006).

\section{KESIMPULAN}

Hasil penelitian ini menunjukan bahwa variable ROCE, CR, DER, TATO secara bersama - sama secara simultan berpengaruhi positif dan signifikan terhaadap Manajemen Laba. variasi variable ROCE secara parsial tidak mempunyai pengaruh yang signifikan terhadap Manajemen Laba. variasi variable CR secara parsial mempunyai pengaruh yang signifikan terhadap Manajemen Laba. variasi variable DER secara parsial mempunyai pengaruh positif yang signifikan terhadap Manajemen Laba. variasi variable TATO secara parsial mempunyai pengaruh signifikan terhadap Manajemen Laba Dan hasil penelitian juga menunjukan bahwa variable ROCE, CR, DER, TATO dan Manajemen Laba secara bersama - sama mempengaruhi simultan positif dan signifikan terhaadap Rating Obligasi. variasi variable ROCE secara parsial mempunyai pengaruh dan signifikan terhadap Rating Obligasi. variasi variable DER secara parsial tidak berpengaruh signifikan terhadap rating obligasi. variasi variable DER secara parsial tidak berpengaruh signifikan terhadap rating obligasi. variasi variable TATO secara parsial mempunyai pengaruh yang signifikan terhadap peringkat obligasi. variasi variable Manajemen Laba secara parsial mempunyai pengaruh yang signifikan terhadap peringkat obligasi.

\subsection{Saran}

Berdasarkan kesimpulan hasil analisis penelitian ini, maka dapat dikemukakan saran - saran sebagai berikut :

1. Bagi peneliti berikutnya, disarankan untuk menambahkan variabel lain sebagai pendukung, misalnya pada rating obligasi terdapat waktu penagihan kewajiban jangka pendek, guna memperkuat seberapa besar nilai kewajiban jangka pendek yang dapat di bayar sesuai jatuh tempo pembayaranya, sehingga rating obligasinya pun semakin baik.

2. Bagi PT. Pefindo penelitian ini menyarankan agar ada penilaian khusus sebelum memberikan peringkat, agar dapat menilai apakah perusahaan yang akan di peringkati mengaplikasikan manajemen laba atau tidak. Dengan demikian laporan keuangan yang akan di nilai untuk mendapatakan peringkat yang baik tidak merasa di bohongi atau di manupulasi laporan keuangannya.

3. Bagi perusahaan penelitian ini dapat sebagai pertimbangkan untuk meningkatkan rating obligasi dengan kinerja keuangan perusahaan supaya 
menghasilkan kinerja keuangan yang bagus dan memiliki hasil rating obligasi perusahaan tanpa mengaplikasikan manajemen laba sehingga para pengguna tidak merasa di manipulasi. Dan menngunakan etika dalam pencatatan dan pelaporan laporan keuangan. Baik bagi kepentingan perusahaa internal maupun kepentingan umum.

4. Bagi calon kreditur atau kreditur di sarankan menganalisis laporan keuaangan dan resiko perusahaan, dengan memperhitungkan kemungkinan perusahaan menggunakan manajemen laba, sehingga dalam pengambilan keputusan calon kreditur atau kreditur mendapatkan informasi yang akurat dan dapat di andalkan.

\section{DAFTAR PUSTAKA}

Abdul Aziz, Muh. Rasio Likuiditas, Rasio Solvabilitas dan Rasio Profitabilitas terhadap Price Book Value (PBV) pada Perusahaan Food and Beverage tahun 2012-2014. Universitas Muhammadiyah Surakarta.

Bringham dan Houston. 2010. Dasar-Dasar Manajemen Keuangan Essentials of financial Management. Jakarta : Salemba Empat.

Ginting, Markoni Hartanta. 2010. Pengaruh Rasio Keungan Terhadap Peringkat Obligasi Perusahaan yang Terdaftar di Bursa Efek Indosnesia. Skripsi Universitas Sumatra Utara.

Kasmir, 2011, “Analisis Laporan Keuangan”, Rajagrafindo persada, Jakarta.

Liukani, Teuta. 2013. Earnings Management and Firm Sise : An Empirical Analyze in Albanian Market.

Pandutama, Arvian. 2012. Faktor-faktor yang Mempengaruhi Prediksi Peringkat Oblgasi pada Perusahaan Manufaktur di BEI. Jurnal Ilmiah Mahasiswa Akuntansi-vil1. No..Juli 2012.

Prihadi, Toto. 2008. 7 Analisis Rasio Keuangan. PPM penerbit. Jakarta.

Rice. 2013. Pengaruh Leverage, Kepemilikan Institusional, Ukuran dan Nilai Perusahaan terhadap Tindakan Manajemen Laba. Jurnal Wira Ekonomi Mikroskil Vol. 3, No. 1, April.

Sekaran, Uma. 2014. Metodologi Penelitian Untuk Bisnis Edisi 4 - Buku 1. Salemba Empat. Jakarta.

Sekaran, Uma. 2014. Metodologi Penelitian Untuk Bisnis Edisi 4 - Buku 2. Salemba Empat. Jakarta.

Shelly Midesia, Hasan Basri, M. Shabri Abd. Majid, Pengaruh Rasio Aktivitas, Profitabilitas, dan Pasar Terhadap Return Saham : Studi banding antara Saham Konvensional dan Saham Syariah DI Indonesia. Pascasarjana Universitas Syiah Kuala

Subramanyam, K. R. dan Wild, John. J. 2008. Analisis Laporan Keuangan Edisi $10^{\text {th }}$ ed. Salemba Empat. Jakarta.

Wiyadi, Rina Trisnawati, Noer Sasongko, dan Ichwani Fauzi. 2015. The Effect of Information Asymmetry, Firm Size, Leverage, Profitability and Employee 
Stock Ownership on Earnings Management With Accrual Model. International Journal Of Business, Ekonomic and Law Vol. 8, Issue 2, Dec.

http://jihadi.staff.umm.ac.id/2011/09/intervening-dan-moderating/

http://khairoelanwar.blogspot.co.id/2014/03/positive-accounting-theory.html 